Karstenia 40: 11-21, 2000

\title{
Some new or interesting sequestrate Basidiomycota from African woodlands
}

\author{
MICHAEL A. CASTELLANO, ANNEMIEKE VERBEKEN, RUBEN WALLEYN and DANIEL THOEN
}

CASTellano, M.A., VerbeKEN, A., WALlEyN, R. \& THOEN, D. 2000: Some new or interesting sequestrate Basidiomycota from African woodlands. - Karstenia 40: 11-21. Helsinki. ISSN 0453-3402.

Five new or interesting sequestrate Basidiomycotina from the Zambezian miombo woodlands of central Africa are described or reported: Aroramyces Castellano \& Verbeken gen. nov., Aroramyces radiatus (Lloyd) Castellano, Verbeken \& Walleyn comb. nov., Corditubera bovonei, Mackintoshia persica, Mycoamaranthus congolensis (Dissing \& Lange) Castellano \& Walleyn comb. nov., and Octaviania ivoryana Castellano, Verbeken \& Thoen sp. nov. In addition, Aroramyces gelatinosporus (Cribb) Castellano comb. nov., from tropical North Queensland, Australia, is presented.

Keywords: ectomycorrhizal hypogeous fungi, miombo woodland, taxonomy, tropical Africa

Michael Castellano, United States Department of Agriculture, Forest Service, Pacific Northwest Research Station, Forestry Sciences Laboratory, Corvallis, Oregon 97331, U.S.A.

Annemieke Verbeken and Ruben Walleyn, Vakgroep Biologie, Lab. Plantkunde, K.L. Ledeganckstraat 35, B-9000 Gent, Belgium

Daniel Thoen, Fondation Universitaire Luxembourgeoise, Av. De Longwy 185, B-6700 Arlon, Belgium

\section{Introduction}

Few sequestrate Basidiomycotina have been reported from Africa south of the Sahara. Most reports concern descriptions of new taxa based on a single collection. Castellano and Trappe (1990) list 21 species and varieties from various countries in sub-Saharan Africa. Sequestrate fungi are more difficult to discover than classical mushrooms, for their habit is to fruit beneath litter, duff or the soil surface. The relative paucity of collecting of sequestrate fungi on the African continent makes it likely that many more species remain undiscovered.

Many sequestrate fungi belong to fungal families within which a majority of the species are thought to form ectomycorrhiza with host plants.
Africa traditionally was thought to be low in diversity of ectomycorrhizal host plants. Meanwhile, through 1992, 51 African plant species in 19 genera have been confirmed as forming ectomycorrhiza (Thoen, 1993). These species belong to the plant families Leguminosae (Caesalpinioideae and Papilionoideae), Euphorbiaceae, Dipterocarpaceae, and Proteaceae. Large vegetation zones, such as the Zambezian and Sudanian woodlands, and parts of the Guineo-Congolian rainforest, are dominated by these ectomycorrhizal trees.

During a collecting trip in drier Zambezian miombo woodland in Zimbabwe, Walleyn and Verbeken found several sequestrate fungi, which 
appeared not uncommon, especially under Brachystegia spiciformis Benth. These collections are studied here together with a few isolated collections from African woodland, sent over the last 15 years to the senior author for identification.

As we honor the contributions of Marja Härkönen, who published several papers on the mushroom flora of Tanzania, it is timely to present a number of species of tropical African sequestrate fungi that we feel can be confidently placed in the mycological scheme of things.

\section{Materials and methods}

Methods of collection and macroscopic and microscopic study were generally those of Castellano et al. (1989). Herbarium names are abbreviated according to Holmgren et al. (1990). Colors of fresh specimens are in general terms. Hand-cut sections of both fresh and dried material were mounted in $5 \% \mathrm{KOH}$ or Melzer's reagent for standard light microscopy. Spore dimensions are based on the measurement of 30 randomly selected spores mounted in $\mathrm{KOH}$; spore lengths include sterigmal attachment. Measurements of sterile tissues (e.g., peridium) and spores are from mature sporocarps. Names of vegetation types follow White (1983).

\section{Taxonomic treatment}

Aroramyces Castellano \& Verbeken, gen. nov. $=$ Radiogaster Lloyd (as McGinty), Mycol. Writings 7, Mycol. Notes 73: 1304. 1925 (invalid, nom. prov., Art. 34.1 a \& b).

Basidiomata subglobosa ad irregularia; superficies tomentosa. Gleba ex rubro brunnea, loculis irregularibus. Rhizomorphae singulae vel numerosae, concolorae. Columella gelatinosa, distincta. Peridium usque ad stratis tribus, ex hyphis intermixtis, fibulatis. Trama ex hyphis hyalinis vel leviter refractivis, compacte et irregulare intermixtis, infibulatis, in matrico gelatinoso. Basidia hyalina, parieto tenui, bispora vel tetraspra. Sporae symmetricae, inamyloideae, nondextrinoideae, spinis in utriculo saccato inflato inclusis ornatae. Typus: Aroramyces gelatinosporus (Cribb) Castellano.

Type: Aroramyces gelatinosporus (Cribb) Castellano.

Basidiomata subglobose to irregular, surface tomentose, numerous soil particles adhering to all sides. Gleba some shade of red to brown; locules irregular, empty or partially filled. Rhizomorphs single or numerous, concolorous with peridium. Columella gelatinous, distinct. Peridium up to three layers, clamp connections present on interwoven hyphae. Trama of hyaline to slightly refractive, densely compacted, unorganized hyphae in a gelatinized matrix, clamp connections absent. Basidia hyaline, thinwalled, 2-4-spored. Spores ornamented with spines embedded within a nearly uniformly inflated utricle, symmetrical, utricle distinct, saccate, inflated, attached only at base, in $\mathrm{KOH}$ some shade of brown singly, nondextrinoid, inamyloid. Etymology: named for David Arora of Santa Cruz, California, accomplished mycologist and collector of numerous fungi in the miombo woodlands of central Africa.

Aroramyces radiatus (Lloyd) Castellano, Verbeken \& Walleyn, comb. nov. - Figs. 1, 5, 9

$=$ Hymenogaster radiatus Lloyd, Mycol. Writings 7, Mycol. Notes 73: 1304. 1925.

= Gymnoglossum radiatum (Lloyd) Bottomley, Bothalia 4: 499. 1948.

= Dendrogaster radiatus (Lloyd) Zeller \& Dodge, Ann. Missouri Bot. Gard. 21: 688. 1934.

Basidiomata up to $2.5(-3.3) \mathrm{cm}$ in diam, subglobose to irregular, when fresh white to yellowwhite with yellow-brown mottling, red-brown where handled, surface tomentose, numerous soil particles adhering to all sides, Guaiac immediately blue, FeSO4 slowly pale blue-green, $\mathrm{KOH}$ slightly red around margin of droplet. Gleba slightly yellow-brown to red-brown to salmon; locules irregular, empty to partially filled. Rhizomorphs single or numerous, stout, up to $1.0 \mathrm{~mm}$ in diam, concolorous with peridium. Columella distinct, gelatinous, opaque, truncate, branched from near center of sporocarp. Odor sometimes strong, raphanoid or sweet. Taste mild.

Peridium three-layered, up to $400 \mu \mathrm{m}$ thick, epicutis 100-150 $\mu \mathrm{m}$ thick, of thin-walled, hyaline, loosely interwoven hyphae 5-7.5 $\mu \mathrm{m}$ in diam, up to about $40 \mu \mathrm{m}$ in length, hyaline crystalline particles abundant on hyphae near surface, clamp connections present; mesocutis variable in thickness, of hyaline, thin-walled, loosely interwoven hyphae with clavate end cells 7.5-10 $\mu \mathrm{m}$ in diam, end cells $13-27 \mu \mathrm{m}$ in diam, clamp connections absent; subcutis 60-75 mm thick, of hyaline, thin-walled, compactly interwoven hyphae $2-3 \mu \mathrm{m}$ in diam with some intergrading clavate cells from adjoining layer.

Trama of hyaline to slightly refractive, densely compacted, unorganized hyphae up to $7.5 \mu \mathrm{m}$ in diam in a gelatinized matrix, clamp connections 
absent. Basidia soon collapsed, hyaline, thinwalled, squat cylindrical to clavate $10 \times 22 \mu \mathrm{m}$, (2-) 4-spored.

Spores ornamented with spines embedded within a nearly uniformly inflated utricle, $10-12$ $(-13.5) \times 6-7(-8) \mu \mathrm{m},($ mean $=10.8 \times 6.85,1 / \mathrm{w}=$ 1.58 ), broadly ellipsoid, symmetrical, base appears truncate owing to how the utricle is attached at the base of the spore, walls $1-1.5 \mu \mathrm{m}$ thick, utricle distinct, saccate, inflated up to $1 \mu \mathrm{m}$, giving the spore a more or less square appearance, attached only at base, in $\mathrm{KOH}$ pale brown singly, golden brown in mass, nondextrinoid, inamyloid.

Habit, habitat and season: Single to gregarious; hypogeous to emergent on litter-rich termite mounds or on doleritic red clay soils in miombo woodland under Brachystegia spiciformis or Uapaca sp.; February and March.

Collections examined: Zimbabwe, Harare ("Salisbury“), March 1920 F. Eyles 2530 (holotype SRGH, isotypes OSC, BPI); Mashonaland East Prov., Bromley, Liemba Farm, Carters Estates, 1.II.1999 A. Verbeken 99-062 (OSC, GENT); ibid., 3.II.1999 A. Verbeken 99101, 99-102, 99-103 (OSC, GENT); Manicaland Prov., Penhalonga, Harris' Garden, 9.II.1999 A. Verbeken 99148, 99-151 (OSC, GENT); Manicaland Prov., Chipinge, Busi Farm, forests around Scott's house, 12.II.1999 A. Verbeken 99-193 (OSC, GENT). 2909)

Iconography: Lloyd (1925, pl. 298, figs. 2908-

Discussion: Lloyd (1925) described this species in Hymenogaster Vittad., but at the same time provisionally introduced the generic name Radiogaster stating "This should be held as a genus (Radiogaster McG.) for it departs from Hymenogaster in several particulars. There are no gleba cells visible to the naked eye, no sterile base, in fact no 'base' at all for on splitting a specimen the gleba appears to radiate from the center. The spores closely resemble those shown by Tulasne for Hymenogaster lycoperdineus and mostly have toothed remains of the sterigmata giving the truncate effect of Ganoderma spores". Lloyd erred in thinking the gleba radiated from the center. He had the misfortune of "splitting" the specimen exactly across its axis instead of in cross-section. Aroramyces radiatus has a distinct columella which if cut through incorrectly would give the impression of a radiating glebal structure. Placement in Dendrogaster Buchholz and Gymnoglossum Massee by Dodge and Zeller (1934), and Bottomley (1948), respectively, is incorrect. The type of Dendrogaster, $D$. connectens Buchholz has been shown by Fogel (1985) to be an immature Hymenogaster and possesses an apical beak characteristic of Hymenogaster. According to Smith (1966) Gymnoglossum has fusoid, smooth, thick-walled spores that have an apical pore. We propose the new genus Aroramyces based on the unique combination of spore characters and gelatinized gleba. Aroramyces has affinities to the Cortinariaceae based on spore pigmentation and ornamentation. The gelatinized gleba and distinctly inflated utricle instantly separates it from all known genera of sequestrate Cortinariaceae. In this genus we include another similar species, known from Queensland, with larger spores and a single-layered peridium:

Aroramyces gelatinosporus (Cribb) Castellano, comb. nov.

= Hysterangium gelatinosporum Cribb, Paps. Dept. Bot. Univ. Queensland 3: 156. 1958.

It is interesting to point out that this genus is only known from subtropical or tropical habitats in Zimbabwe and Queensland, Australia. The collections of A. gelatinosporus from Queensland are all from under various Eucalyptus (Myrtaceae) species, the collections from Zimbabwe are from under Brachystegia (Caesalpinioideae) and Uapaca (Euphorbiaceae).

Corditubera bovonei (Mattir.) Demoulin \& Dring, Bull. Jard. Bot. Belg. 45: 347. 1975.

= Scleroderma bovonei Mattirolo, Bull. Jard. Bot. Etat 8: 30. 1922.

Basidiomata subglobose to globose, mottled yellow to yellow-brown with scattered off-white areas when fresh, distinctly rugulose, mottled pale gray and pale brown when dried. Gleba solid, nearly black with white to off-white veins. Rhizomorphs scattered, thin, yellow-brown. Columella absent. Taste not determined. Odor not determined.

Peridium two-layered, up to $1330 \mu \mathrm{m}$ thick; epicutis up to $760 \mu \mathrm{m}$ thick, of compact textura epidermoidea, slightly pale yellow-brown, thinwalled hyphae up to $8 \mu \mathrm{m}$ thick; subcutis up to $570 \mu \mathrm{m}$ thick, of compact textura epidermoidea, hyaline, thin-walled hyphae up to $15 \mu \mathrm{m}$ thick; clamp connections absent from both layers. 


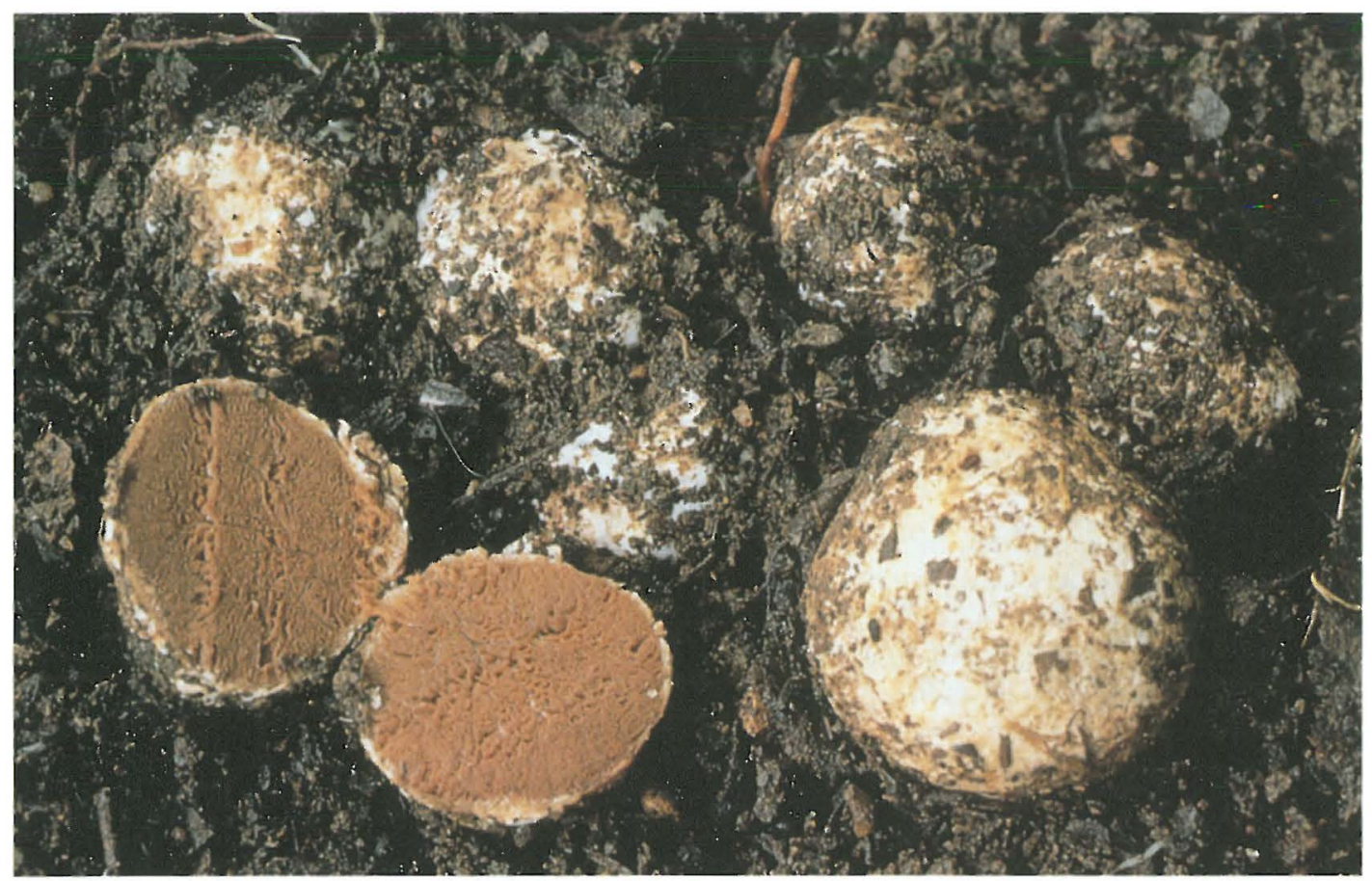

Fig. 1. Aroramyces radiatus (A. Verbeken 99-103). (Photo: R. Walleyn).

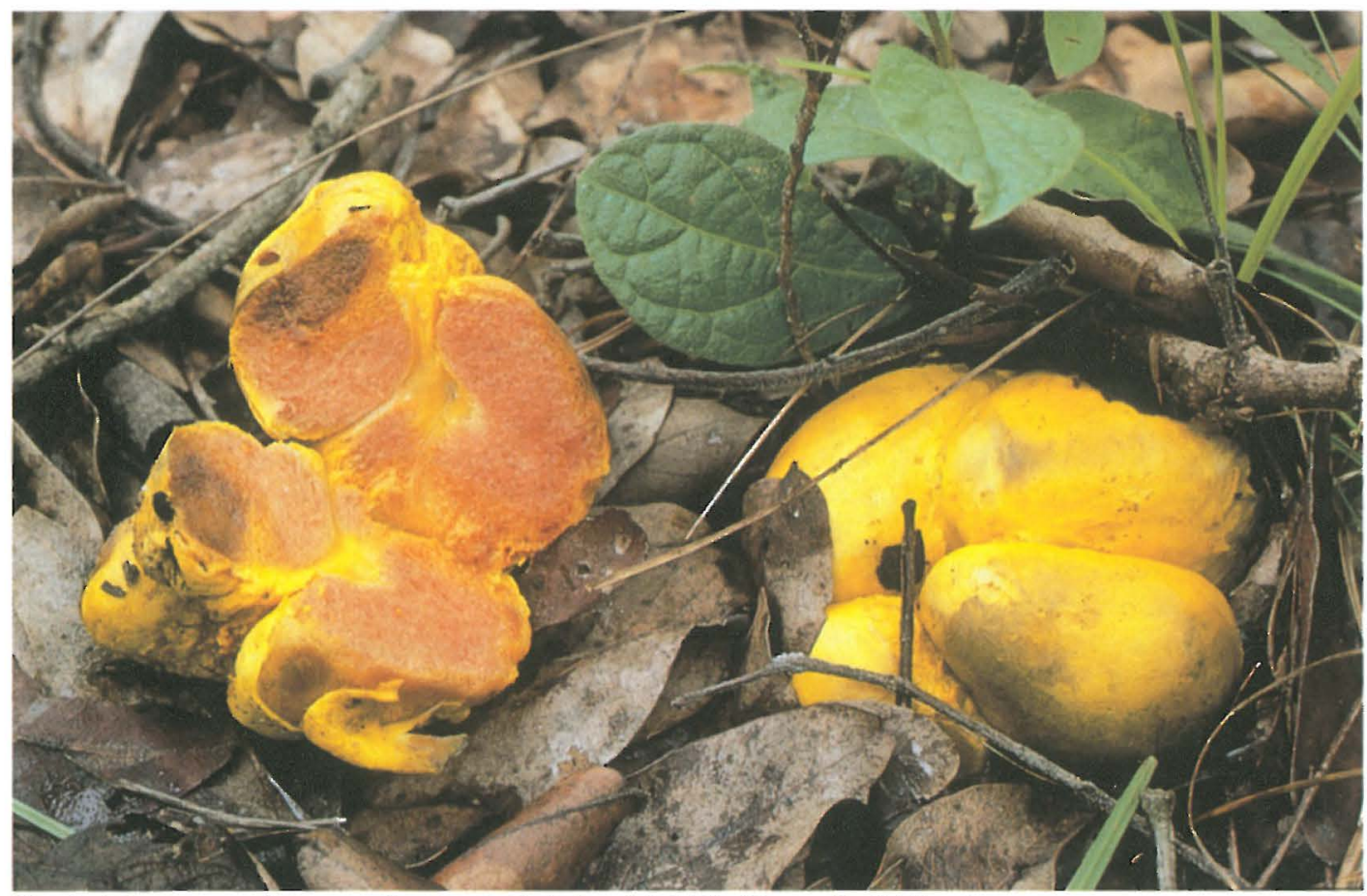

Fig. 2. Mycoamaranthus congolensis (A. Verbeken 99-105). (Photo: R. Walleyn). 


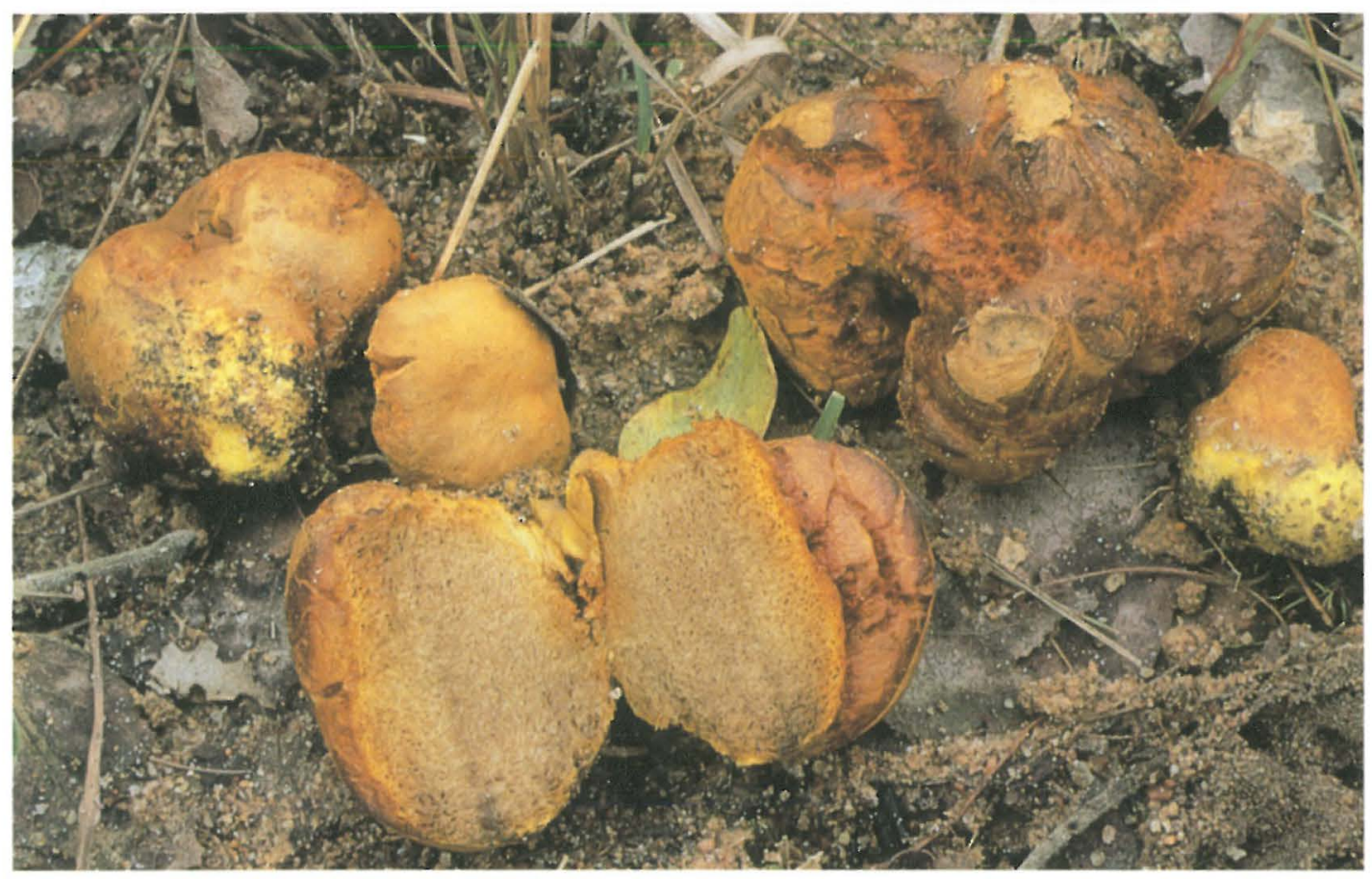

Fig. 3. Mackintoshia persica (A. Verbeken 99-169). (Photo: R. Walleyn).

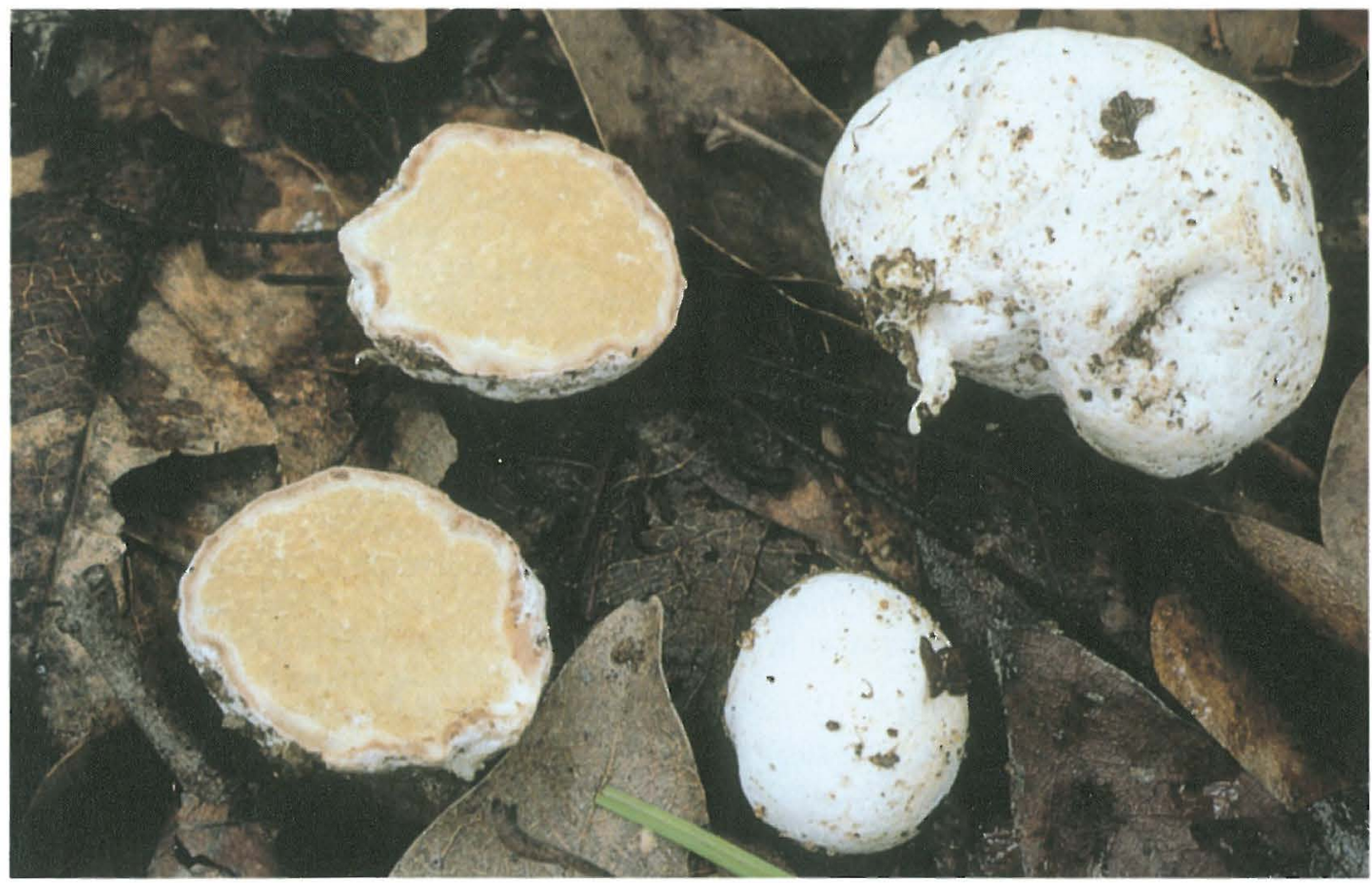

Fig. 4. Octaviania ivoryana, holotype in situ. (Photo: R. Walleyn). 
Trama of hyaline, compact textura epidermoidea, hyphae up to $5 \mu \mathrm{m}$ thick; clamp connections absent. Hymenium not seen. Basidia not seen but remnant hyaline, sterigmal attachments can be observed. Cystidia absent.

Spores ornamented with spines or punctations, 9-11 $(-13) \mu \mathrm{m}$, including ornamentation subglobose to globose, sometimes variously angled or flattened, symmetrical, ornamented uniformly with minute spines or a minute punctation, walls $1-2 \mu \mathrm{m}$ thick except at point of attachment where the spore wall is thin, in $\mathrm{KOH}$ pale yellow-brown singly, yellow-brown in mass.

Habit, habitat and season: subhypogeous to emergent through leaves in miombo woodland under Brachystegia spiciformis; February.

Collections examined: Zimbabwe, Manicaland Prov., Chipinge, Busi Farm, around Scott's house, 12.II.1999 A. Verbeken 99-189 (OSC, GENT).

Iconography and figs.: Mattirolo (1922, pl. 2), Dissing \& Lange (1962, fig. 60D; 1964, pl. 42, fig. 11), Demoulin \& Dring (1975: figs. 3ab).

Discussion: We did not examine the type but our specimens agree with the description of the type by Dissing and Lange (1962). The minute ornamentation of the spores lead Mattirolo (1922) to originally describe them as smooth. Corditubera kivuensis Demoulin and Dring differs by its smaller spores and more distinct ornamentation.

Mackintoshia persica Pacioni \& Sharp, Mycotaxon 75: 226. 2000. - Figs. 3, 7, 10

Collections examined: Zimbabwe, Manicaland Prov., along Mutare-Bvumba road, near Prins Charles Viewpoint, 11.II.1999 A. Verbeken 99-169 (GENT, OSC); Manicaland Prov., Chipinge, Busi Farm, forest around Scott's house, 13.II.1999 A. Verbeken 99-210 (GENT, OSC).

The collections cited represent additional localities of this species that very recently has been described by Pacioni and Sharp (2000). For a full description on this fungus we refer to this publication.

Mycoamaranthus congolensis (Dissing \& Lange) Castellano \& Walleyn, comb. nov. - Figs. $2,8,11$

= Dendrogaster congolensis Dissing \& Lange, Bull. Jard. Bot. Etat 32: 335. 1962.
Basidiomata up to $40 \mathrm{~mm}$ wide and $30 \mathrm{~mm}$ tall, irregular, subglobose to globose to somewhat wrinkled and knobby, vivid yellow when fresh and remaining so at base but becoming slightly brown or olive over upper portion with age, when fresh peridium thin, membranous, arachnoid in places, easily separable from gleba, surface slightly tomentose, dry, somewhat powdery. Gle$b a$ firm, spongy-rubbery, pink in youth, becoming yellow-red, salmon to gray-red or dull red when mature; locules minute, irregularly shaped. Rhizomorphs scanty, emergent from base, concolorous with peridium. Columella extending up from sterile base, concolorous with peridium. Taste acrid and mealy. Odor indistinct or unpleasant, of plastic.

Peridium with yellow pigment immediately leached from peridial tissue when mounted in $\mathrm{KOH}$, leaching of pigment not evident in $\mathrm{H}_{2} \mathrm{O}$ or Melzer's reagent, single layered, up to $600 \mu \mathrm{m}$ thick, of pale yellow to brown-yellow, thin-walled hyphae 5-8 $\mu \mathrm{m}$ in diam in a textura epidermoidea, subpericlinal near gleba (within 100-200 $\mu \mathrm{m}$ ), more loosely interwoven near peridial surface, with some encrustations on the hyphae near the surface; clamp connections absent.

Trama of hyaline, loosely interwoven, multibranched, thin-walled hyphae, 4-5 $\mu \mathrm{m}$ in diam, in a gelatinized matrix; clamp connections absent. Hymenium a single palisade of basidia. Basidia clavate to broadly clavate, hyaline, $24-28 \times(12-)$ 13-15 $\mu \mathrm{m}$ at the apex, 4-spored; sterigmata 5-7 (-8) $\mu \mathrm{m}$ long, $2 \mu \mathrm{m}$ wide at base, tapered; clamp connections absent. Cystidia absent, although in one collection (99-105) some unusual elements were observed emerging from the hymenium, they were narrowly cylindrical, hyaline, $23-38 \times 4-5 \mu \mathrm{m}$.

Spores ornamented, (11-) 12-15 × 8-10 $\mu \mathrm{m}$ (mean $=12.9 \times 8.7 \mu \mathrm{m}, 1 / \mathrm{w}=1.49$ ) excluding ornamentation but including pedicel, ellipsoid to broadly ovoid, symmetrical, ornamented uniformly with minute spines, approximately $0.5 \mu \mathrm{m}$ tall, walls $1-1.5(-2) \mu \mathrm{m}$ thick, sterigmal attachment distinct, hyaline, $2 \mu \mathrm{m}$ long $\times 1 \mu \mathrm{m}$ wide, spines and walls dextrinoid in youth, nondextrinoid at maturity, in $\mathrm{KOH}$ hyaline singly, pale yellow-brown in mass.

Habit, habitat and season: Single to gregarious; subhypogeous to emergent through leaves on doleritic red clay soils in miombo woodland under Brachystegia spiciformis, Julbernardia 

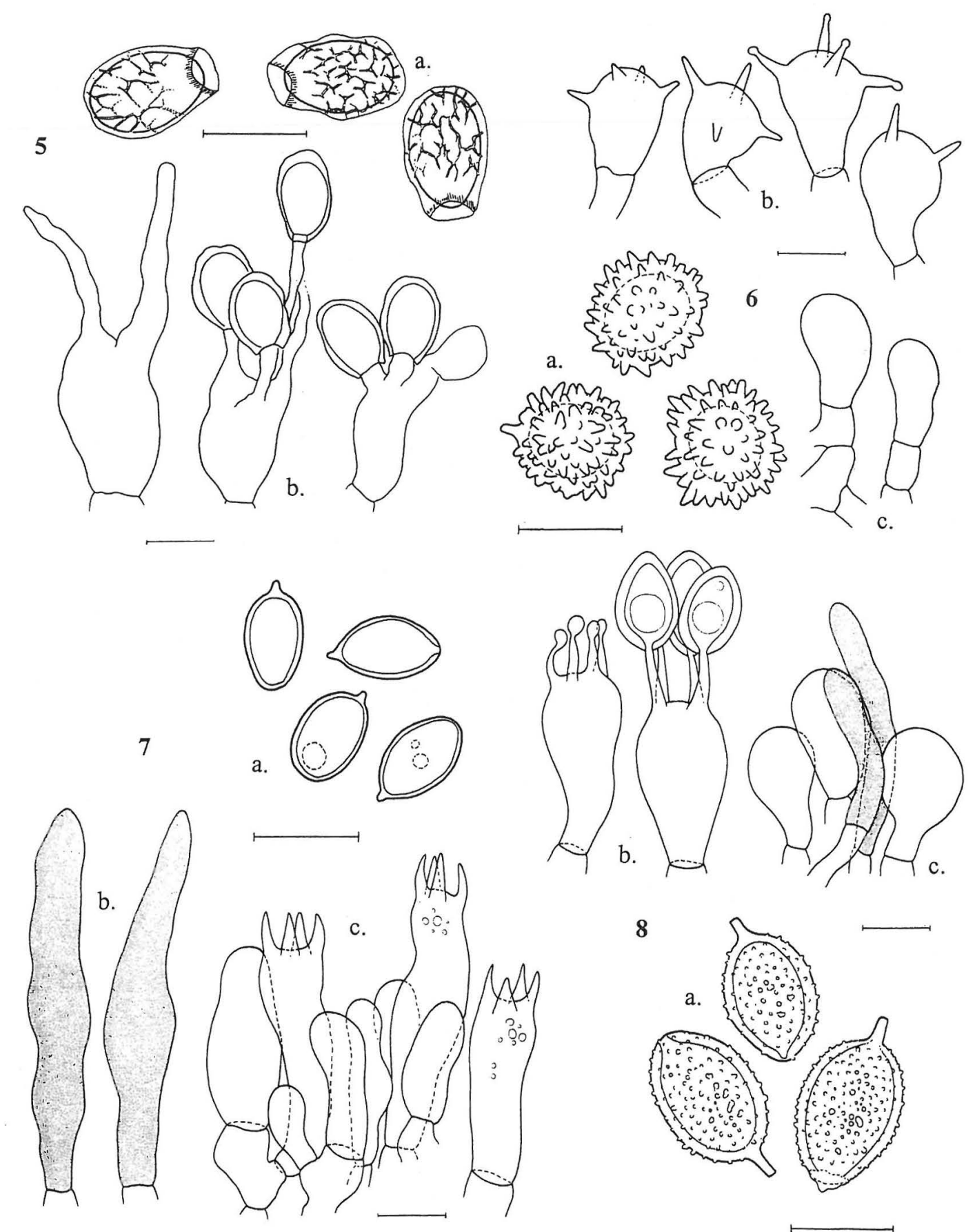

Figs. 5-8. - 5. Aroramyces radiatus. a. spores, b. basidia (A. Verbeken 99-148). - 6. Octaviania ivoryana. a. spores, b. basidia, c. basidioles (A. Verbeken 99-104) - 7. Mackintoshia persica. a. spores, b. pleurocystidia, c. basidia and basidioles (A. Verbeken 99-169). - 8. Mycoamaranthus congolensis. a. spores, b. basidia, c. basidioles and pleurocystidia (A. Verbeken 99-105). Bar $=10 \mu \mathrm{m}$. 
globiflora (Benth.) Troupin or Uapaca sp.; December through early February.

Collections examined: Congo-Kinshasa, Shilatembo, 19.XII.1972 D. Thoen 5581 (herb. Thoen). Malawi, Malsoa, near Shire River, 30.I.1992 D. Arora 101 (OSC). Zimbabwe, Mashonaland East Prov., Bromley, Liemba Farm, 3.II.1999 A. Verbeken 99-105 (OSC, GENT); Manicaland Prov., Penhalonga, Harris' Garden, 9.II.1999 A. Verbeken 99-150 (OSC, GENT); Manicaland Prov., Chimanimani, 3.II.1992 D. Arora 72 (OSC): Harare, February 1999 D. Arora 127 (OSC).

Iconography and figs.: Dissing and Lange (1962, fig. 39; 1963, pl. 39, fig. 1).

Local uses: Eaten, first boiled and the dried, by local people in Eastern Burundi who call it 'ugutwikwinkende' (Nzigidahera 1994). In Malawi the people of the Yaowo tribe eat it and their name for it is "haira" (D. Arora, pers. comm.).

Discussion: The type collection is listed from Congo in Haut-Katanga District, in vicinity of "Elizabethville" (Lubumbashi) in December. Illustrations of basidia, spores and sterigmata fit perfectly, except spore width was reported by Dissing and Lange (1962) as 9.4-12 $\mu \mathrm{m}$. Dendrogaster was first described by Buchholz (1901) and reduced to synonymy under Gymnoglossum by Cunningham (1944). Smith (1966) disagreed with Cunningham and placed it in Hymenogaster as a subgenus. After study of the type (D. connectens Buchholz) Fogel (1985) agreed with Smith (1966) that D. connectens was indeed a Hymenogaster species aligned with other Hymenogaster species that possess an apical beak on the spore and some degree of columella development.

Mycoamaranthus was originally described from northern Queensland, Australia (Castellano et al. 1992). The type $M$. auriorbis Castellano, Trappe \& Malajczuk is characterized by a vivid yellow peridium and unique spore ornamentation. Mycoamaranthus congolensis possesses both features but differs from $M$. auriorbis in size of the spores and basidia, both being larger in $M$. congolensis than in $M$. auriorbis. The collection from Thailand cited by Castellano et al. (1992) as $M$. auriorbis is a third, as yet, undescribed species from under Dipterocarpaceae.

Octaviania ivoryana Castellano, Verbeken \& Thoen, sp. nov. - Figs. 4, 6, 12
Basidiomata usque ad $50 \mathrm{~mm}$ diam., subglobosa, globosa, reniformia vel pyriformia, ex glauco alba cum maculis griseis vel cremeis; superficies ceracea vel leviter pruinosa; gustu indistincto; odore pomi similis. Gleba firma, alba vel rubroflavida, viridiflavida, cum maculis glaucis, loculis irregularibus. Columella interdum presens, alba. Peridium bistratis, 700 $\mu m$ crassum; epicutis usque ad $500 \mu \mathrm{m}$ crassa, ex hyphis hyalinis, gelatinosis, compacte intermixtis, infibulatis, superficiem versus palisadiformis; subcutis usque ad $200 \mu m$ crassa, ex hyphis hyalinis, non gelatinosis, compacte intermixtis. Basidia clavata, 13-20 × 11-12 $\mathrm{m}$, tetraspora, interdum bispora. Sporae hyalinae ad pallide olivaceae in cumulo, 9-12(15) $\times$ (7) 8-10(12) $\mu \mathrm{m}$, late ellipsoideae ad subglobosae, spinis densis, acutis vel reflexis, in conis usque ad $2 \mu \mathrm{m}$ altis coalescentibus ornatae.

Typus: Zimbabwe, Mashonaland East Prov., Bromley, Liemba Farm, 3.II.1999 A. Verbeken 99104 (holotype GENT, isotype OSC).

Basidiomata 10-50 mm in diam, subglobose, globose, reniform to pyriform, when fresh pure white with some small areas that are gray to cream, some blue-green stains and an undefinable pale green tinge, surface waxy, somewhat pitted in places, elsewhere smooth and somewhat powdery. In cross-section the peridium appears two-layered with the outer layer gray-pink and the inner layer pure white. Gleba solid, marbled white and red-yellow, green-yellow to pale yellow olive, sometimes developing blue to bluegreen stains when cut; locules irregularly shaped, filled. Rhizomorphs single to numerous, fine to about $1 \mathrm{~mm}$ wide, attached at sporocarp base, white. Columella present or absent, when present white. Taste not distinctive. Odor sweet, pleasant, slightly apple-like.

Peridium two-layered, up to $700 \mu \mathrm{m}$ thick, epicutis up to $500 \mu \mathrm{m}$ thick, of hyaline to pale gray, thin-walled, gelatinized, compactly interwoven hyphae, 3-4 $\mu \mathrm{m}$ in diam, with many erect hyphal tips forming a turf at the surface, clamp connections absent; subcutis up to $200 \mu \mathrm{m}$ thick, of hyaline, thin-walled, nongelatinized, tightly interwoven hyphae 5-8 $\mu \mathrm{m}$ in diam.

Trama 20-50 $\mu \mathrm{m}$ thick, of hyaline, divergent, slightly gelatinous, thin-walled hyphae, $2-4 \mu \mathrm{m}$ in diam, clamp connections absent. Basidia soon collapsed, clavate, 13-20 × 11-12 $\mu \mathrm{m},(2-)$ 4-spored; sterigmata $2-5 \mu \mathrm{m}$ tall, $1-2 \mu \mathrm{m}$ wide at base. 


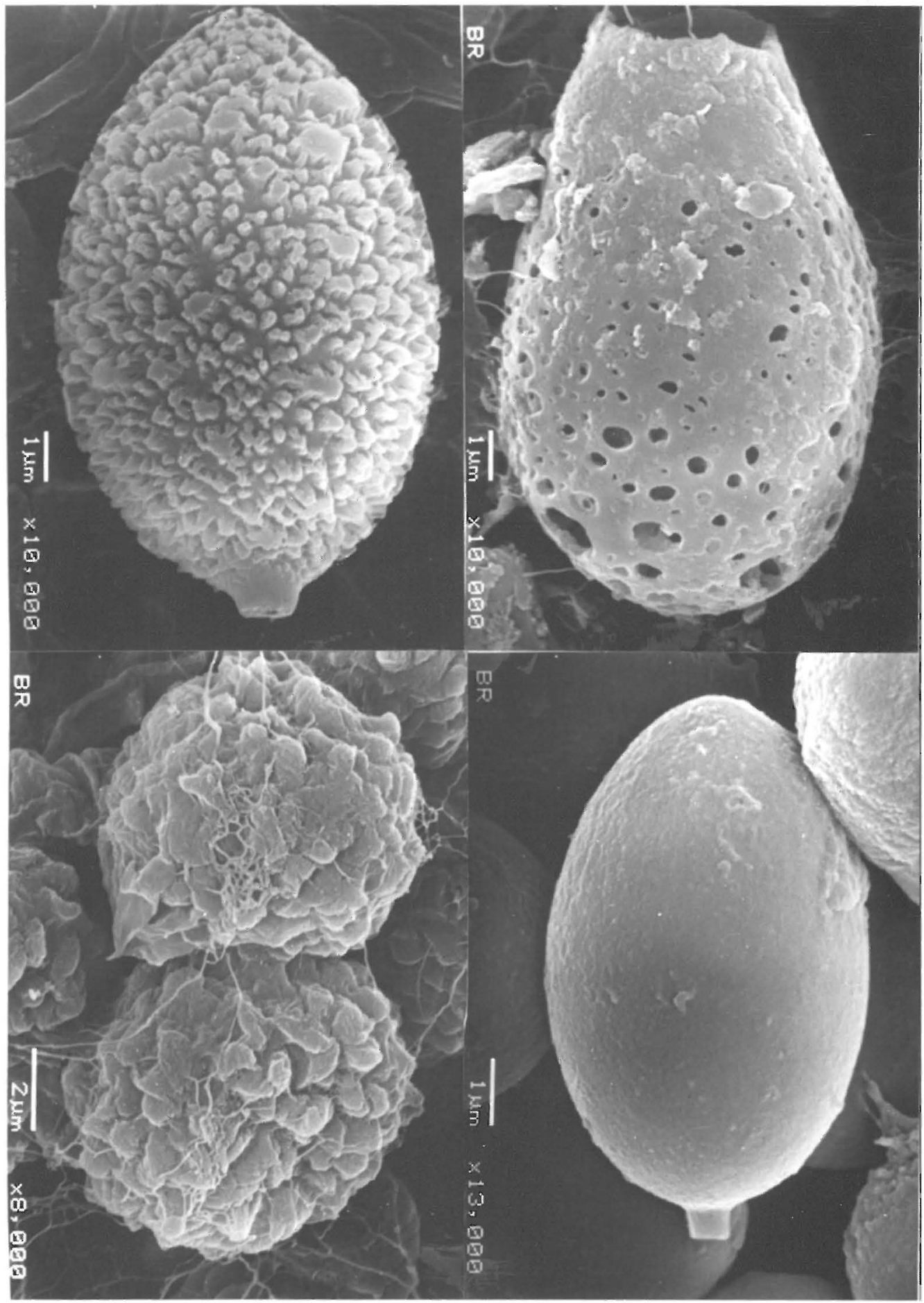

Figs. 9-12. SEM photographs of spores. - 9. Aroramyces radiatus (A. Verbeken 99-148). - 10. Mackintoshia persica (A. Verbeken 99-169). - 11. Mycoamaranthus congolensis (A. Verbeken 99-105). - 12. Octaviania ivoryana (holotype). 
Spores ornamented, 9-12 (-15) $\times(7-) 8-10(-$ 12) $\mu \mathrm{m},($ mean $=10.5 \times 9.1 \mu \mathrm{m}, 1 / \mathrm{w}=1.17)$, broadly ellipsoid to subglobose, ornamented with crowded, pointy to reflexed spines coalesced into cones, 1-2 $\mu \mathrm{m}$ tall, ornamentation radiates somewhat from point of attachment, symmetrical, thick-walled more or less $1 \mu \mathrm{m}$ thick, in $\mathrm{KOH}$ hyaline to pale yellow-green singly, hyaline to pale olive in mass, dextrinoid, inamyloid.

Etymology: "ivoryana," named in honor of Michael H. Ivory, of the Oxford Forestry Institute, accomplished collector of sequestrate fungi in far flung regions of the world.

Habit, habitat and season: Single to gregarious; subhypogeous to emergent through leaves on doleritic red clay soils in miombo woodland or on termite mounds under Afzelia africana Smith ex Pers., A. quanzensis Welw., Anthonotha crassifolia (Baill.) Léonard, Brachystegia spiciformis, or Uapaca sp.; July through September (Sudanian woodland) and January, February (Zambezian miombo woodland).

Additional collections examined: Zimbabwe, Manicaland Prov., Chimanimani, 3.II.1992 D. Arora 73 (OSC); Lake McLlvaine, 10.I.1992 D. Arora 13 (OSC); Msina Ranch, 7.I.1999 C. Sharp $1197 / 99$ (OSC, GENT); Mukuvisi, February 1992 D. Arora 126 (OSC). Kenya, Gede Forest Office, 5.VIII.1995 M. Ivory 978 (OSC). Guinea, Lébékéré, 14.VII.1988 D. Thoen 7958 (OSC, herb. Thoen). Senegal, Prov. de Kolda, Thiara, 17.VIII.1987 A.M. Ba, D. Thoen 7861 (OSC, herb. Thoen); Prov. de Kolda, Thiara, 25.VIII.1986 D. Thoen 7660 (OSC, herb. Thoen); Prov. de Kolda, Thiara, 23.IX.1986 D. Thoen 7701 (OSC, herb. Thoen); Prov. de Kolda, 29.VII.1988 D. Thoen 8011 (herb. Thoen).

Iconography: Thoen and Ducousso (1989, fig. 9e).

Discussion: The genus Octaviania Vittad. is characterized by dextrinoid spores ornamented with distinct cones of coalesced spines. We have not studied material of Octaviania africana Lloyd but its larger spores, as published in the description by Bottomley (1948), Lloyd (1922) and Verwoerd (1925), separate it from Octaviania ivoryana.

The specimens $D$. Thoen 7660, 7701, 7861 and 7958 were cited as Sclerogaster sp. by Thoen and $\mathrm{Ba}(1989)$ and Thoen and Ducousso (1989).

It should be noted that the Nomenclatural Committee for Fungi recently pointed out that Octavianina is a later orthographic variant of Octaviania, not to be used (Gams 1999).
Acknowledgements: The National Fund for Scientific Research - Flanders (F.W.O., Belgium) granted the collecting trip of A. Verbeken in Zimbabwe. Mieke and Ruben wish to thank the families Sharp, Carter and Scott for their kind hospitality received during their stay in "Zim". The S.E.M. photographs were made by Marcel Verhaegen at the National Botanic Garden of Belgium (BR). Pacioni and Sharp are thanked for communicating their paper on Mackintoshia. Thom Kuyper (The Netherlands) kindly solved the nomenclatural discussion on Radiogaster.

\section{References}

Bottomley, A.M. 1948: Gasteromycetes of South Africa. - Bothalia 4: 473-544.

Buchholz, F. 1901: Hypogaeen aus Russland. - Hedwigia 40: 304-322.

Castellano, M.A., \& Trappe, J.M. 1990: Australasian truffle-like fungi. I. Nomenclatural bibliography of type descriptions of Basidiomycotina. - Australian Syst. Bot. 3: 653-670.

Castellano, M.A., Trappe, J.M., \& Malajczuk, N. 1992: Australasian truffle-like fungi. III. Royoungia gen. nov. and Mycoamaranthus gen. nov. (Basidiomycotina). - Aust. Syst. Bot. 5: 613-616.

Castellano, M.A., Trappe, J.M., Maser, Z., \& Maser, C. 1989: Keys to spores of the genera of hypogeous fungi of north temperate forests with special reference to animal mycophagy. -Mad River Press, Eureka, California. 186 pp.

Cunningham, G.H. 1944: The Gasteromycetes of Australia and New Zealand. - John McIndoe, Dunedin (New Zealand). 236 pp.

Demoulin, V. \& Dring, D.M. 1975: Gasteromycetes of Kivu (Zaire), Rwanda and Burundi. - Bull. Jard. Bot. Belg. 45: 339-372.

Dissing, H. \& Lange, M. 1962: Gasteromycetes of Congo. - Bull. Jard. Bot. Etat 32: 325-416.

Dissing, H. \& Lange, M. 1963: Gasteromycetales I. - Fl. Iconogr. Champignons Congo 12: 215-232, pl. 3840.

Dissing, H. \& Lange, M. 1964: Gasteromycetales II. Fl. Iconogr. Champignons Congo 13: 233-252, pl. 41-43.

Dodge, C.W. \& Zeller, S.M. 1934: Hymenogaster and related genera. - Ann. Missouri Bot. Gard. 21: 625705.

Fogel, R. 1985: Studies on Hymenogaster (Basidiomycotina): A re-evaluation of the subgenus Dendrogaster. - Mycologia 77: 72-82.

Gams, W. 1999: Report of the Committee for Fungi: 8. - Taxon 48: 807-810.

Holmgren, P.K., Holmgren, N.H., \& Barnett, L.C. 1990: Index Herbariorum. Edition 8. Part I. The Herbaria of the World. - Regnum Vegetabile 120: 1-693.

Lloyd, C.G. 1922: Mycological Writings, Mycol. Notes 7: 1142

Lloyd, C.G. 1925: Mycological Writings, Mycol. Notes 7: 1304 . 
Mattirolo, O. 1922: Un nouveau champignon hypogé du Congo Belge Scleroderma bovonei Mattirolo. - Bull. Jard. Bot. Etat. 8: 23-37.

Nzigidahera, B. 1994: Etude de la répartition et de l'exploitation des écosystèmes naturels de CankuzoEst. - Ministère de l'Environnement et de l'Aménagement Territoire, Inst. Nat. Environ. Conserv. Nature. Projet APRN/GTZ, Bujumbura (Burundi). 83 pp. +20 pp. annexes.

Pacioni, G. \& Sharp, C. 2000: Mackintoshia, a new sequestrate basidiomycete genus from Zimbabwe. Mycotaxon 75: 225-228.

Smith, A.H. 1966: Notes on Dendrogaster, Gymnoglossum, Protoglossum and species of Hymenogaster. Mycologia 58: 100-124.

Thoen, D. 1993: Looking for ectomycorrhizal trees and ectomycorrhizal fungi in tropical Africa. - In S. Isaac,
J.C. Frankland, R. Watling, \& J.S. Whalley (eds.): 93205. Aspects of Tropical Mycology, Cambridge University Press.

Thoen, D. \& Ba, A.M. 1989: Ectomycorrhizas and putative ectomycorrhizal fungi of Afzelia africana and Uapaca guineensis in Southern Senegal. - New. Phytol. 113: 549-559.

Thoen, D. \& Ducousso, M. 1989: Champignons et ectomycorrhizes du Fouta Djalon. - Bois Forêts Trop. 221: 45-63.

Verwoerd, L. 1925: A contribution to our knowledge of the South African Hymenogastraceae. - S. Afr. J. Sci. 22: $161-166$.

White, F. 1983: The vegetation of Africa. A descriptive memoir to accompany the Unesco/AETFAT/UNSO vegetation map of Africa. - Paris, Unesco. 356 pp. 